\title{
$J$

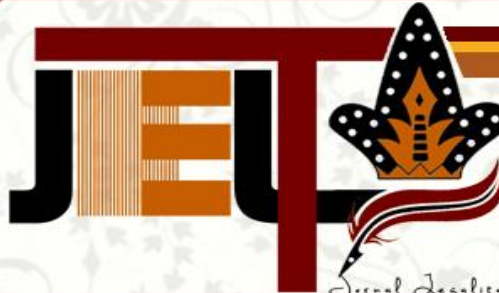 \\ LEMAHNYA KEPOLISIAN DALAM PENANGANAN TINDAK PIDANA PERJUDIAN TOGEL ONLINE
}

\section{“Weak Polices In Handling Criminal Actions Online Togel Gaming”}

\author{
Aniza Lakoro, Lisnawaty W. Badu, Nuvazria Achir \\ Fakultas Hukum Universitas Negeri Gorontalo. Gorontalo, Indonesia \\ Korespondensi: Email: Anizalakoro@gmail.com
}

\begin{abstract}
ABSTRAK
Penelitian ini bertujuan untuk mengetahui bagaimana bentuk modus operandi serta upaya kepolisian dalam penanganan tindak pidana perjudian togel online di Kota Gorontalo. Jenis Penelitian yang digunakan oleh peneliti dalam menyusun Penelitian ini adalah jenis Penelitian normatif-empiris, Adapun pendekatan yang digunakan oleh peneliti dalam menyusun penelitian ini adalah, antara lain: Pendekatan Perundang-Undangan (Statue Approach); Pendekatan kasus (case approach). Hasil penelitian menunjukkan bahwa upaya kepolisian dalam penanganan tindak pidana perjudian togel online ini pertama mereka melakukan Pertama sosialisasi, meminta bantuan kepada aparat - aparat desa juga mungkin menghimbau kepada mereka biar lebih aktif agar tidak melakukan perjudian. Kedua, Patroli Rutin Aparat Kepolisian Resort Gorontalo Kota, kegiatan ini sebenarnya adalah salah satu tugas rutin dari Kepolisian Resort Gorontalo Kota yang bertujuan untuk memberikan rasa aman dan penertiban pada wilayah hukum Polres Gorontalo Kota ini dan agar tidak terjadi lagi hal - hal yang seperti itu. Dan faktor penghambat dalam penanganan tindak pidana perjudian togel online yakni peran kepolisian dalam menangani kasus perjudian online belum begitu efektif dikarenakan masih adanya hambatanhambatan yang ditemukan dalam proses penanggulangan tindak pidana tersebut, diantaranya adalah kendala IT yang masih terbatas, sehingga terhadap pelaku judi tersebut hanya dikenakan Pasal 303 KUHP tentang perjudian. Dan dalam penanganan kasus judi online pun mengalami beragam hambatan yang ditemukan dilapangan baik dari segi waktu, biaya dan proses yang tidak mudah dibayangkan.
\end{abstract}

\section{Kata Kunci : Upaya kepolisian; Tindak pidana perjudian; Togel online}

\begin{abstract}
This study aims to determine how the modus operandi and the efforts of the police in handling the crime of online lottery gambling in Gorontalo City. This type of research used by researchers in compiling this research is a type of normative-empirical research. The approaches used by researchers in compiling this research are, among others: The Legislative Approach (Statue Approach); The case approach. The results showed that the police's efforts in handling the crime of online lottery gambling were first carried out by them. First, socialization, asking for help from village officials, they might also urge them to be more active so they don't gamble. Second, the Routine Patrol of the Gorontalo City Resort Police, this activity is actually one of the routine tasks of the Gorontalo City Resort Police which aims to provide a sense of security and order to the jurisdiction of the Gorontalo City Police and so that things like that do not happen again. And the inhibiting factor in handling the crime of online lottery gambling, namely the role of the police in handling online gambling cases has not been very effective because there are still obstacles found in the process of overcoming the crime, including IT constraints that are still limited, so that the gambling perpetrator is only subject to Article 303 of the Criminal Code concerning gambling. And in handling online gambling cases, there are various obstacles found in the field, both in terms of time, cost and process that are not easy to imagine.
\end{abstract}

Keywords: Police efforts; Gambling crime; Online lottery 


\section{PENDAHULUAN}

\section{A. Latar Belakang}

Perjudian bukanlah hal baru atau suatu bentuk permainan baru bagi masyarakat Indonesia karena permainan judi sebenarnya sudah ada sejak dulu dan berkembang secara subur sejalan dengan perkembangan jaman. Perjudian merupakan salah satu penyakit masyarakat yang dalam sejarah dari generasi ke generasi ternyata tidak mudah untuk diberantas. Pengertian penyakit masyarakat adalah segenap tingkah laku manusia yang dianggap tidak sesuai dengan norma-norma yang ada di dalam masyarakat dan adat istiadat atau tidak terintegrasi dengan tingkah laku umum. ${ }^{1}$ Perjudian ini di atur dalam Pasal 303 dan 303 bis KUHP.

Tindak pidana perjudian selain diatur di dalam Pasal 303 dan Pasal 303 bis KUHP, juga diatur di dalam Pasal 45 ayat (2) UndangUndang Nomor 19 Tahun 2016 tentang perubahan atas Undang-Undang Nomor 11 Tahun 2008 tentang Informasi dan Transaksi Elektronik. Menurut Duwi Handoko, tidak terdapat pola pidana minimum terhadap pelaku tindak pidana perjudian, baik yang diatur di dalam maupun di luar KUHP (diatur dalam UU ITE). Ditinjau dari kualifikasi

1 Kartono, Kartini, Patologi Sosial Jilid 1. (Jakarta: Rajagrafindo Persada, 2011), Hal. 53

2 Duwi Handoko. 2018. Tindak Pidana Tanpa Korban Di Indonesia Pengaturan dan Problematikanya, Jurnal Menara Ilmu, 3 (3): 38 ancaman pidana, ancaman pidana bagi pelaku perjudian berdasarkan KUHP adalah bersifat alternatif, yaitu terhadap pelaku dapat dikenakan pidana penjara atau pidana denda. Sedangkan menurut UU ITE, ancaman pidana bagi pelaku perjudian adalah bersifat kumulatif alternatif, yaitu terhadap pelaku dapat dikenakan pidana penjara saja, atau dikenakan pidana penjara dan pidana denda sekaligus. Pengaturan tindak pidana perjudian selain diatur dalam Hukum Pidana Umum (di dalam KUHP), juga diatur dalam Hukum Pidana Khusus (di luar KUHP). ${ }^{2}$

Seiring dengan perkembangan teknologi dan informasi yang kian pesat, kegiatan berjudi pun mengalami peralihan ke judi online yang lebih praktis dan lebih aman dilakukan. Fenomena judi online yang sekarang marak terjadi adalah judi togel online, yang banyak sekali ditemukan di tengah masyarakat terutama di warungwarung internet, atau dengan menggunakan laptop dalam menjalankan aktivitas tersebut, atau bahkan lewat smartphone yang memiliki fasilitas pendukung atau aplikasi pendukung bermain judi togel online. ${ }^{3}$

3 Asrul Azis. 2012. "Perkembangan Hukum Mengenai Pemberantasan Judi Toto Gelap (Togel) dalam Perspektif Kriminologi," Jurnal Ilmiah, Medan: Fakultas Hukum Universitas Sumatra Utara. Hal. 2 
Penegakan hukum pidana untuk menanggulangi perjudian sebagai perilaku yang menyimpang harus terus dilakukan. Hal ini sangat beralasan karena perjudian merupakan ancaman yang nyata terhadap norma-norma sosial yang dapat menimbulkan ketegangan individual maupun keteganganketegangan sosial. Perjudian merupakan ancaman rill atau potensiil bagi berlangsungnya ketertiban sosial. ${ }^{4}$ Apabila ada pelaku tindak pidana perjudian maka orang tersebut akan di pidanakan sebagaimana sistem peradilan pidana yang ada di Indonesia.

Upaya dan peranan penegak hukum sangat berperan penting dalam memberantas setiap tindak pidana. Kepolisian sebagai salah satu penegak hukum diharapkan dapat mencegah dan menanggulangi serta memberantas tindak pidana perjudian. Hal tersebut merupakan tugas pokok Kepolisian Republik Indonesia (Polri) menurut UndangUndang Nomor 2 Tahun 2002 Tentang Kepolisian Negara Republik Indonesia. ${ }^{5}$

Tugas pokok Kepolisian Negara Republik Indonesia diatur dalam Pasal 13 Undang-Undang Nomor 2 Tahun 2002 Tentang Polri, yaitu: ${ }^{6}$ Memelihara keamanan

4 Karolina Sitepu. 2015. Pemberantasan dan Penanggulangan Tindak Pidana Perjudian Togel di Wilayah Hukum Polresta Medan, Jurnal Ilmiah, Medan: "RESEARCH SAINS" 1 (1): 10

5 Yuda Pramudia Zen, Skripsi: "Upaya kepolisian dalam menanggulangi tindak pidana perjudian yang dan ketertiban masyarakat; Menegakan hukum; Memberikan perlindungan, pengayoman, dan pelayanan kepada masyarakat.

Didalam menyelenggarakan tugas memelihara keamanan dan ketertiban masyarakat tersebut dicapai melalui tugas preventif dan tugas represif. Tugas dibidang preventif dilaksanakan dengan konsep dan pola pembinaan dalam wujud pemberian pengayoman, perlindungan dan pelayanan kepada masyarakat, agar masyarakat merasa aman, tertib dan tentram tidak terganggu segala aktifitasnya. Langkah preventif adalah usaha mencegah bertemunya niat dan kesempatan berbuat jahat, sehingga tidak terjadi kejahatan atau kriminalitas. ${ }^{7}$

Penegakan hukum pidana untuk penanggulangan perjudian mengalami hambatan-hambatan dalam pelaksanaannya. Salah satu hambatannya, karena perjudian telah menjadi kebiasaan bagi kalangan tertentu. Ironinya, kadang pola pikir para pelaku judi menganggap hal itu wajar dan sah untuk dilakukan. Lebih mencemaskan, secara statistik terjadi peningkatan modus dari tindak pidana perjudian. Hal ini dapat terlihat dari

dilakukan oleh remaja di wilayah hukum kepolisian resor kota padang", (Padang: Universitas Andalas, 2017), Hal. 4-5

${ }^{6}$ Ibid

7 Sadijono, Hukum Kepolisian, (Yogyakarta: Laksbang Pressindo, 2006), Hal. 119 
menjamurnya perjudian di tiap-tiap wilayah kota yang ada di indonesia. ${ }^{8}$

Khususnya di Kota Gorontalo, dalam tiga tahun terakhir terdapat 13 kasus perjudian togel online. Kepolisian harusnya melakukan pengembangan lebih lanjut terhadap tindak pidana perjudian yang terjadi dalam penanganan secara keseluruhan praktekpraktek perjudian togel yang ada di Kota Gorontalo.

Usaha pemerintah dan para aparat penegak hukum untuk penanganan dan membatasi perjudian menjadi terhambat dengan banyaknya praktek-praktek perjudian gelap. Perjudian merupakan penyakit masyarakat yang juga dapat merugikan ekonomi rakyat dan terhadap hukum, dampaknya terhadap ekonomi rakyat adalah banyaknya harta benda yang terjual hanya karena dipertaruhkan. ${ }^{9}$

Selain itu juga judi dapat merusak hubungan rumah tangga yang dapat berantakan karena suami istri yang suka bermain judi. Terhadap aspek hukum perjudian merupakan suatu bentuk tingkah laku atau perbuatan yang melanggar norma

8 Muh Nur Fadlan, Skripsi: "Tinjauan Yuridis Terhadap Tindak Pidana Perjudian Di Kabupaten Gowa Tahun 2006-2011", (Makassar: UIN Alauddin, 2012), Hal. 3

9 https://docplayer.info/37550461-Perankepolisian-dalam-memberantas-tindak-pidanajudi-sabung-ayam-di-kota-gorontalo-studi-kasus- atau aturan-aturan adat, agama dan tentunya norma hukum. Reaksi sosial terhadap perjudian tersebut cukup keras, bukan saja dari kalangan agama melainkan juga organisasi-organisasi kemasyarakatan dan kalangan lain yang peduli terhadap masalah judi ini. ${ }^{10}$

Berdasarkan hasil wawancara Bersama Bapak Amirullah Mohamad sebagai administrasi di Sat Reskrim Polres Gorontalo Kota, telah ditemukan adanya kasus Tindak Pidana Perjudian Togel Online di Kota Gorontalo. Sebagaimana data awal yang berhasil dihimpun peneliti di Polres Gorontalo Kota seperti tabel dibawah ini: ${ }^{11}$

Tabel : 1

Jumlah Pelaku Tindak Pidana Perjudian Togel Online

\begin{tabular}{lcc}
\hline No. & Tahun & Judi Togel \\
\hline 1 & 2016 & 6 \\
\hline 2 & 2017 & 3 \\
\hline 3 & 2018 & 4 \\
\hline \multicolumn{3}{r}{ Berdasarkan data yang peniliti dapatkan, } \\
bahwa kasus & tindak pidana & perjudian togel \\
dari tahun 2016 terdapat 6 kasus, adapula pada
\end{tabular}

di-polres-gorontalo-kota.html. Diakses pada 24 Oktober pukul 12.12

10 Mulyana W Kusuma, Kejahatan Dan Penyimpangan, (Jakarta : YLBHI, 1988), Hal. 55

11 Hasil wawancara bersama Penyidik Satuan Reskrim, Bapak Amirullah Mohamad, Polres Gorontalo Kota, Rabu 13 Maret 2019. 
tahun 2017 terdapat 3 kasus, sementara pada tahun 2018 terdapat 4 kasus.

\section{B. Rumusan Masalah}

Berdasarkan penjelasan latar belakang permasalahan di atas, maka dapat dirumuskan masalah dalam penelitian ini, yakni sebagai berikut:

1. Bagaimana upaya kepolisian dalam penanganan tindak pidana perjudian togel online di kota gorontalo?

2. Apakah faktor penghambat dalam penanggulangan tindak pidana perjudian togel online di kota gorontalo?

\section{Metode Penelitian}

Jenis Penelitian yang digunakan oleh peneliti dalam menyusun Penelitian ini adalah jenis Penelitian normatif-empiris, Adapun pendekatan yang digunakan oleh peneliti dalam menyusun penelitian ini adalah, antara lain: Pendekatan Perundang-Undangan (Statue Approach); Pendekatan kasus (case approach).

\section{PEMBAHASAN}

\section{A. Upaya Kepolisian Dalam Penanganan Tindak Pidana Perjudian Togel Online di Kota Gorontalo}

Kejahatan merupakan entitas yang selalu lekat dengan dinamika perkembangan peradaban umat manusia. Kejahatan disebut sebagai perilaku menyimpang, selalu ada dan melekat pada tiap bentuk masyarakat, tidak ada masyarakat sepi dari kejahatan.
Oleh karena itu, upaya penanggulangan kejahatan sesungguhnya merupakan upaya yang terus menerus dan berkesinambungan. Tidak ada, bahkan tidak akan pernah ada upaya yang bersifat final. Dalam hal ini dimaksudkan bahwa setiap upaya penanggulangan kejahatan tidak dapat manjanjikan dengan pasti bahwa kejahatan itu tidak akan terulang atau tidak akan memunculkan kejahatan baru. Namun demikian, upaya itu tetap harus dilakukan untuk lebih menjamin perlindungan dan kesejahteraan masyarakat.

Dengan semakin majunya peradaban manusia, sebagai implikasi dari perkembangan ilmu pengetahuan dan teknologi, muncul berbagai jenis kejahatan berdimensi baru, yang termasuk di dalamnya cyber crime. Sejalan dengan itu diperlukan upaya penanggulangan untuk menjamin ketertiban dalam masyarakat. Dalam perspektif hukum, upaya ini direalisasikan dengan hukum pidana. Hukum pidana diharapkan mampu memenuhi cita ketertiban masyarakat.

Akan tetapi dalam menghadapi perkembangan masyarakat, hukum pidana tidak selamanya mampu menjawab terhadap dampak negatif yang timbul, yang biasa disebut dengan kejahatan. Ini dikarenakan teknologi yang membawa perubahan dalam 
masyarakat berkembang begitu pesat, Kota, menyikapinya dengan melakukan sementara hukum pidana merupakan produk sejarah yang sudah barang tentu berjalan dalam logika sejarah yang menaunginya, walaupun dalam batas tertentu mempunyai prediktabilitas atas perkembangan masyarakat.

Perbuatan pidana adalah perbuatan yang oleh suatu aturan hukum dilarang dan diancam pidana, asal saja dalam pada itu diingat bahwa larangan ditunjukan kepada perbuatan, (yaitu suatu keadaan dan kejadian yang ditimbulkan oleh kelakuan orang), sedangkan ancaman pidananya ditunjukan kepada orang yang menimbulkan kejadian itu. Perjudian adalah tempat untuk mencari uang tapi dengan cara haram, jika mendengar kata perjudian, seketika itu langsung berpikir pada uang yang dibuat judi. Selama ini aparat Kepolisian tetap mengandalkan upaya pencegahan dan penanggulangan perjudian togel yang sifatnya lebih memasyarakat dalam artian pendekatanpendekatannya dilakukan dengan bantuan kerjasama dari masyarakat. Karena hanya upaya inilah yang diharapkan bagi seluruh masyarakat Indonesia mampu untuk mencegah dan menanggulangi perjudian togel yang saat ini masih marak terjadi.

Sehubungan dengan langkah kepolisian dalam melakukan penanggulangan kasus judi online di wilayah Gorontalo, Polres Gorontalo 
mereka biar lebih aktif agar tidak melakukan perjudian.

2. Patroli Rutin Aparat Kepolisian Resort Gorontalo Kota, kegiatan ini sebenarnya adalah salah satu tugas rutin dari Kepolisian Resort Gorontalo Kota yang bertujuan untuk memberikan rasa aman dan penertiban pada wilayah hukum Polres Gorontalo Kota ini dan agar tidak terjadi lagi hal - hal yang seperti itu.

(b) Langkah represif

Langkah represif dilakukan jika telah terbukti yang disangkakan terhadap pelaku merupakan kasus tindak pidana, maka secara hukum akan diproses. Dalam hal penanggulangan, Polres Gorontalo Kota masih kesulitan dan mengalami hambatan dalam hal IT. Dalam melakukan penyelidikan dan penyidikan misalnya dengan cara melacak nomer hp walaupun masih banyak terkendala. Kemudian dalam pembuatan berita acara pemeriksaan (BAP) dengan melakukan pemeriksaan terhadap jaringan komunikasi yang dibentuk pelaku dan bisa jadi dari keterangan saksi yang diperoleh. Kemudian dari segi alat bukti yang ditemukan dan buktibukti terkait merupakan sarana penal yang dilakukan dalam menumpas perjudian di Polres Gorontalo Kota.
Dalam penjelasan lebih lanjut, mengenai pembuktian dan kesaksian terdakwa dalam proses pemeriksaan terdakwa bahwa pembuktian berasal dari bukti komunikasi terdakwa dalam melayani pembeli, uang menjadi barang bukti yang disita dalam pemeriksaan. Mengenai detail komunikasi yang dilakukan antara terdakwa dengan pemasang, pemakai, atau oknum - oknum yang lain yang terkait dalam jaringan judi online, maka ditanyakan dalam berita acara pemeriksaan (BAP). Selain itu pembuktian lainnya bisa berasal dari keterangan saksi.

Penyidik menerapkan Pasal 45 ayat (2) Undang-Undang Nomor 19 Tahun 2016 tentang perubahan atas Undang-Undang Nomor 11 Tahun 2008 tentang Informasi dan Transaksi Elektronik dan Pasal 303 KUHP untuk Tindak Pidana Perjudian secara online yang dilakukan oleh pelaku tersebut. Walaupun sudah ada peraturan yang mengatur tentang perjudian secara online, penyidik tetap mencantumkan Pasal 303 KUHP sebagai salah satu pasal yang dilanggar oleh pelaku. Padahal Pasal 303 KUHP merupakan pasal yang mengatur tentang perjudian secara konvensioal.

Penerapan Pasal 303 KUHP pada tindak pidana perjudian secara online sebenarnya kurang tepat karena pada Pasal 303 KUHP tidak diatur mengenai unsur-unsur teknologi 
informasi, sedangkan yang dinamakan sebagai tindak pidana perjudian secara online pasti menggunakan sarana teknologi informasi, baik itu melalui SMS, internet dan sebagainya. Menurut Peneliti seharusnya pasal yang dikenakan oleh penyidik terhadap para pelaku tindak pidana perjudian secara online Pasal 45 ayat (2) Undang-Undang Nomor 19 Tahun 2016 tentang perubahan atas Undang-Undang Nomor 11 Tahun 2008 tentang Informasi dan Transaksi Elektronik, tidak perlu menggunakan Pasal 303 KUHP lagi. Karena sanksi pidana pada UU ITE lebih berat dibandingkan Pasal 303 KUHP, sehingga diharapkan dapat memberikan efek jera terhadap para pelaku.

Berdasarkan hasil wawancara dengan penyidik, urutan dari penegakan hukum terhadap tindak pidana perjudian secara online yang dilakukan oleh pelaku dimulai dari tertangkap tangannya pelaku oleh Penyidik Polres Gorontalo Kota, sehingga laporan polisinya menggunakan model A, dimana petugas menemukan secara langsung atau para pelaku tertangkap tangan melakukan suatu tindak pidana. Secara lengkap urut-urutannya adalah sebagai berikut:

1. Pada proses pertama, karena petugas melakukan tangkap tangan kepada para pelaku judi online, maka petugas menerbitkan laporan polisi terkait tindak pidana perjudian secara online. Laporan Polisi adalah laporan tertulis yang dibuat oleh petugas Polri tentang adanya suatu peristiwa yang diduga terdapat pidananya baik yang ditemukan sendiri maupun melalui pemberitahuan yang disampaikan oleh seseorang karena hak atau kewajiban berdasarkan peraturan perudangundangan.

Laporan Polisi dalam Peraturan Kapolri (Perkap) No 14 Tahun 2012 tentang Manajemen Pendidikan Tindak Pidana terdiri dari 2 (dua) jenis yaitu sebagai berikut:

1) Laporan Polisi model A, dan

2) Laporan Polisi model B

Pada kasus perjudian secara online yang ditangani oleh Penyidik Polres Gorontalo Kota, menggunakan Laporan Polisi model A sesuai dengan Perkap No 14 Tahun 2012 tentang Manajemen Pendidikan Tindak Pidana, Pasal 5 ayat (2) Perkap No 14 Tahun 2012 menyebutkan pengertian Laporan Polisi model A sebagai berikut, Laporan Polisi model A adalah Laporan Polisi yang dibuat oleh anggota Polri yang mengalami, 
mengetahui atau menemukan langsung peristiwa yang terjadi.

2. Kemudian penyidik melakukan pemeriksaan saksi-saksi yang terkait dalam tindak pidana judi online tersebut dan memeriksa barang bukti, guna membuat terang tindak pidana perjudian online yang terjadi.

3. Selanjutnya penyidik melakukan gelar perkara. Gelar perkara dilakukan guna menentukan tersangka, menentukan perbuatan tersebut merupakan sebuah tindak pidana atau bukan dan menentukan unsur-unsur pasal yang dipersangkakan.

Gelar Perkara menurut Pasal 1 angka 17 Peraturan Kepala Badan Reserse Kriminal Kepolisian Republik Indonesia (Perkaba) No 4 Tahun 2014 tentang Standar Operasional Prosedur Pengawasan Penyidikan Tindak Pidana menyebutkan:

Gelar Perkara adalah kegiatan penyampaian pejelasan tentang proses atau hasil penyelidikan oleh penyidik kepada peserta gelar perkara dalam bentuk diskusi kelompok untuk mendapatkan tanggapan, masukan, koreksi dalam rangka menghasilkan rekomendasi untuk menentukan tindak lanjut proses penyidikan.
4. Setelah dilakukan gelar perkara, penyidik melakukan Penetapan tersangka.

Pasal 1 butir 14 KUHAP memberikan pengertian mengenai Tersangka yang berbunyi, Tersangka adalah seorang yang karena perbuatannya atau keadaannya, berdasarkan bukti permulaan patut diduga sebagai pelaku tindak pidana.

Untuk penetapkan seseorang berstatus tersangka harus memenuhi syaratsyarat yang telah ditentukan, sebagaimana diatur dalam Pasal 66 Peraturan Kapolri Nomor 12 Tahun 2009 tentang Pengawasan dan Pengendalian Penanganan Perkara Pidana di Lingkungan Kepolisian Negara Republik Indonesia, yaitu sebagai berikut:

1) Status tersangka hanya dapat ditetapkan oleh penyidik kepada seseorang setelah hasil penyelidikan yang memperoleh bukti permulaan yang cukup yaitu paling sedikit 2 (dua) jenis alat bukti.

2) Untuk menentukan bukti permulaan tersebut harus ditentukan melalui gelar perkara. 
5. Kemudian penyidik melakukan digital forensik terhadap barang bukti digital di Labfor Polri, untuk memeriksa barang bukti yang telah disita oleh penyidik.

Forensik merupakan suatu kegiatan untuk melakukan investigasi dan menetapkan fakta yang berhubungan dengan suatu tindak kriminal dan permasalahan hukum lainnya. Sedangkan digital forensik merupakan bagian dari ilmu forensik yang melingkupi penemuan dan investigasi materi (data) yang temukan pada perangkat digital seperti; komputer, handphone, tablet, PDA, networking devices dan sejenisnya.

6. Pemeriksaan terhadap ahli-ahli, dalam kasus tindak pidana perjudian secara online ahli yang terkait adalah Ahli Informasi dan Transaksi Elektronik (ITE), dan Ahli Digital Forensik.

7. Mengirim berkas perkara tindak pidana perjudian online kepada Jaksa Penuntut Umum (JPU).

Dalam mengirim berkas perkara tindak pidana perjudian secara online ini harus berdasarkan ketentuan yang tercantum dalam KUHAP. Pasal 8 ayat (3) KUHAP, menyebutkan penyerahan berkas perkara ke JPU, yaitu sebagai berikut:

Penyerahan berkas perkara sebagaimana dimaksud dalam ayat (2) dilakukan:

a. Pada tahap pertama penyidik hanya menyerahkan berkas perkara.

b. Dalam hal penyidikan sudah dianggap selesai, penyidik menyerahkan tanggung jawab atas tersangka dan barang bukti kepada penuntut umum.

8. Ketika penyidikan dianggap sudah selesai, maka penyidik menyerahkan tersangka dan barang bukti ke JPU.

Menurut Bapak Melki Naue, Penyidik Sat Reskrim Gorontalo Kota (wawancara 13 Januari 2020) mengatakan bahwa $:^{12}$

"Upaya kepolisian dalam penanganan tindak pidana perjudian togel online ini sudah menjadi tugasnya kami dan untuk melakukan atau mengantisipasi ataupun memberantas perjudian-perjudian online seperti ini memang agak sulit untuk mengungkap pelaku-pelakujudi online ini karena butuh pembuktian-pembuktian
12 Hasil wawancara bersama Bapak Melki Naue, Penyidik Satuan Reskrim, Polres Gorontalo Kota, Senin 13 Januari 2020 
juga, dan pembuktian yang dimaksud yaitu ketika kedapatan pada saat penangkapan proses judi online ini kami harus meminta akun yang digunakan untuk bermain judi itu dan harus kami uji dulu. Kami menguji dengan labolatorium forensik kemudian hasil dari ujiannya itu kami jadikan alat bukti yang cukup atau kami jadikan alat bukti untuk menindaki orang yang bermain judi dalam perkara perjudian togel online ini."

Melihat dengan adanya upaya dari kepolisian maka judi togel online di kota gorontalo ini dari tahun ke tahun sudah agak berkurang karena dengan efek jeranya mereka yang sudah terpidana dengan kasus ini mungkin sudah jadi pembelajaran juga kepada yang lain.

\section{B. Faktor Penghambat Dalam Tindak Pidana Perjudian Togel Online di Kota Gorontalo}

Mengenai pasal perjudian togel yang tercantum dalam Kitab Undang - Undang Hukum Pidana (KUHP):

1. Undang - Undang Nomor 7 Tahun 1947 Tentang Penertiban Perjudian. ${ }^{13}$ Pasal 1
Menyatakan semua tindak pidana perjudian sebagai kejahatan

Pasal 2

(1) Merubah ancaman hukuman dalam Pasal 303 ayat (1) Kitab Undang - Undang Hukum Pidana, dari Hukuman Penjara selama - lamanya dua tahun delapan bulan atau denda sebanyak - banyaknya sembilan puluh ribu rupiah menjadi hukuman penjara selama - lamanya sepuluh tahun atau denda sebanyak banyaknya dua puluh lima juta rupiah.

(2) Merubah ancaman hukuman dalam Pasal 542 ayat (1) Kitab Undang - Undang Hukum Pidana, dari hukuman kurungan selama - lamanya satu bulan atau denda sebanyak - banyaknya empat ribu lima ratus rupiah, menjadi hukuman penjara selama - lamanya empat tahun atau denda sebanyak - banyaknya sepuluh juta rupiah.

13 Undang-Undang Nomor 7 Tahun 1947 Tentang Penertiban Perjudian 
(3) Merubah ancaman hukuman dalam Pasal 542 ayat (2) Kitab Undang - Undang Hukum Pidana, dari hukuman kurungan selama - lamanya tiga bulan atau denda sebanyak - banyaknya tujuh ribu lima ratus rupiah menjadi hukuman penjara selama - lamanya enam tahun atau denda sebanyak - banyaknya lima belas juta rupiah.

(4) Merubah sebutan Pasal 542 menjadi Pasal 303 bis.

2. Pasal 303 Kitab Undang - Undang Hukum Pidana (KUHP) Tentang Tindak Pidana Perjudian.

Tindak pidana dalam hal perjudian dirumuskan dalam dua Pasal, yakni Pasal 303 dan 303 bis, yang kedua Pasal itu merupakan kejahatan.

Kejahatan menawarkan atau memberi kesempatan untuk bermain judi. Kejahatan yang di maksudkan diatas dirumuskan dalam Pasal 303, yang selengkapnya adalah sebagai berikut. ${ }^{14}$

(1) Diancam dengan pidana penjara paling lama sepuluh tahun atau pidana denda paling banyak dua puluh lima juta rupiah, barang siapa tanpa mendapat izin:

1. Dengan sengaja menawarkan atau memberikan kesempatan untuk permainan judi dan menjadikannya sebagai pencaharian, atau dengan sengaja turut serta dalam suatu kegiatan usaha itu;

2. Dengan sengaja menawarkan atau memberi kesempatan kepada khalayak umum untuk bermain judi atau dengan sengaja turut serta dalam kegiatan usaha itu, dengan tidak peduli apakah untuk menggunakan kesempatan adanya sesuatu syarat atau dipenuhinya sesuatu tata-cara;

3. Menjadikan turut serta pada permainan judi sebagai pencaharian. Kalau yang bersalah melakukan kejahatan tersebut dalam menjalankan pencahariannya, maka dapat dicabut haknya untuk menjalankan pencahariannya itu. 
(2) Kalau yang bersalah melakukan kejahatan tersebut dalam menjalankan pencahariannya, maka dapat dicabut haknya untuk menjalankan pencahariannya itu.

(3) Yang disebut dengan permainan judi adalah tiap-tiap permainan, dimana pada umumnya kemungkinan mendapat untung bergantung pada keberuntungan belaka, juga karena pemainnya lebih terlatih atau lebih mahir. Di situ termasuk segala pertaruhan tentang keputusan perlombaan atau permainan lain - lainnya yang tidak diadakan antara mereka yang turut berlomba atau bermain, demikian juga segala pertaruhan lainnya.

3. Pasal 303 bis KUHP Menggunakan Kesempatan Main Judi yang Diadakan dengan Melanggar Pasal 303 Kejahatan mengenai perjudian yang dimaksudkan di atas dirumuskan dalam Pasal 303 bis yang rumusannya sebagai berikut: ${ }^{15}$

(1) Diancam dengan pidana penjara paling lama empat

15 Pasal 303 bis Kitab Undang-Undang Hukum Pidana, Hal. 89 tahun atau pidana denda paling banyak sepuluh juta rupiah;

1. Barang siapa menggunakan kesempatan main judi, yang diadakan dengan melanggar ketentuan Pasal 303;

2. Barang siapa ikut serta main judi dijalan umum atau dipinggir jalan umum atau di tempat yang dapat dikunjungi umum, kecuali jika ada izin dari penguasa yang berwenang yang telah memberi izin untuk mengadakan perjudian itu.

(2) Jika ketika melakukan pelanggaran belum lewat dua tahun sejak ada pemidanaan yang menjadi tetap karena salah satu dari pelanggaran ini, dapat dikenakan pidana penjara paling lama enam tahun atau pidana denda paling banyak lima juta rupiah.

Menurut peneliti togel merupakan bentuk permainan dengan bertaruh uang dengan menebak nomor-nomor yang akan keluar. Dan perjudian ini telah dinyatakan dilarang oleh undang-undang, namun 
perjudian ini sangat sulit untuk diberantas secara keseluruhan di dalam kehidupan masyarakat. Hal tersebut terbukti dengan masih sering dijumpai permainan-permainan yang mengandung unsur perjudian di dalam masyarakat seperti sabung ayam, main kartu dan togel.

Berdasarkan Penelitian yang sudah dilakukan dengan Bapak Amirullah Mohamad sebagai administrasi di Sat Reskrim Polres Gorontalo Kota, telah di temukan adanya kasus Tindak Pidana Perjudian Togel Online di Kota Gorontalo. Sebagaimana data yang berhasil dihimpun oleh peneliti di Polres Gorontalo Kota seperti pada tabel dibawah ini: ${ }^{16}$

Tabel : 1

Jumlah Pelaku Tindak Pidana Perjudian Togel Online

\begin{tabular}{lcc}
\hline No. & Tahun & Judi Togel \\
\hline 1 & 2016 & 6 \\
\hline 2 & 2017 & 3 \\
\hline 3 & 2018 & 4 \\
\hline
\end{tabular}

\section{Sumber Data Polres Gorontalo Kota}

Data yang peniliti dapatkan, bahwa kasus tindak pidana perjudian togel dari tahun 2016 terdapat 6 kasus, adapula pada tahun 2017 terdapat 3 kasus, sementara pada tahun 2018 terdapat 4 kasus.

16 Hasil wawancara bersama Bapak Amirullah Mohamad sebagai administrasi, Polres Gorontalo Kota, Kamis 17 Oktober 2019
Kemunculan judi togel online ini di mulai dengan masuknya teknologi internet di indonesia. Teknologi ini tidak hanya dimanfaatkan untuk kebutuhan politik, ekonomi dan budaya saja akan tetapi juga merambah ke dunia permainan sehingga semakin banyak bermunculan game online salah satunya judi togel online.

Kemunculan permainan judi togel online ini membawa angin segar untuk pecinta game taruhan. Karena mereka bisa lebih bebas dan aman memainkan permainan kegemaran mereka tersebut tanpa harus datang ke agen judi. Dengan bermain secara online, mereka bisa memainkan kapanpun dan dimanapun yang mereka inginkan bahkan tanpa keluar rumah sekalipun.

Dalam togel ini seorang petaruh atau pemasang akan memesan nomor taruhannya kepada pengecer baik itu secara lisan, telepon, ataupun sms, kemudian pengecer tersebut akan menyerahkan semua nomor-nomor taruhannya kepada bandar di atasnya.

Cara permainan judi togel tersebut adalah pada setiap hari senin, rabu, kamis, sabtu dan minggu dari pukul 10:00 WIB sampai pukul 15:00 WIB. Para pemain/pemasang, memasang angka pada 
pengecer sesuai dengan filling masing masing. Selanjutnya jadwal nomor undian keluar sekitar pukul 17.00-18.00 WIB, nomor yang keluar berpatokan dari Negara Singapura. Dan pemain atau pemasang dikatakan menang bila, nomor pasangan tepat/sama dengan angka yang keluar dari Negara Singapura, sedangkan pemain atau pemasang yang kalah, apabila nomor pasangan tidak tepat/tidak sama dengan angka yang keluar dari Negara Singapura. Adapun besarnya uang taruhan yaitu minimal Rp.1000, dan maksimalnya tidak terbatas untuk pasangan 2 (dua) angka dengan taruhan sebesar Rp.1000, yang menang mendapatkan uang sebesar Rp. 70.000, dan untuk 3 (tiga) pasang angka dengan taruhan Rp.1000, bila menang maka akan mendapatkan uang sebesar Rp. 300.000, sedangkan untuk pasangan 4 (empat) angka dengan taruhan Rp.1000, bila menang makan akan mendapatkan uang sebesar Rp. 2.500.000.

Menurut Bapak Melki Naue, Penyidik Sat Reskrim Gorontalo Kota, mengatakan bahwa : ${ }^{17}$

"Modus perjudian togel kan sudah banyak yang beredar dalam media sosial maupun informasi-informasi mungkin dalam bentuk aplikasi-aplikasi yang menyebar luaskan yang mengenai perjudian. Sehingga orang-orang yang kebiasaannya bermain judi togel diluar atau togel offline, mereka ingin mencoba-coba dengan bermain judi melalui online itu."

Cara mereka untuk melakukan togel online :

Di lihat dari pengalaman yang terjadi bahwa mereka menggunakan akun mereka, yang dalam akun tersebut ada situs yang mereka terima kemudian mereka buka tentang masalah perjudian togel online, dan dalam situs itu ada petunjuk-petunjuk yang harus mereka ikuti sehingga mereka mengikuti sesuai dengan apa yang ada dalam situsnya itu. Dengan adanya teknologi yang canggih seperti sekarang ini maka kita tidak susah lagi untuk mengakses semua apa yang kita inginkan.

Untuk mengetahui pelaku tindak pidana perjudian togel online ini, kami hanya mendapatkan informasi-informasi bahwa ada orang yang bermain judi togel online atau ketika kami melaksanakan operasi dan mendapatkan informasi dari dunia mayapun kami proses. Jadi kami hanya mengumpulkan informasi-informasi bahwa memang ada orang yang bermain judi togel online seperti itu.

\footnotetext{
17 Hasil wawancara bersama Bapak Melki Naue, Penyidik Satuan Reskrim, Polres Gorontalo Kota, Senin 13 Januari 2020
} 
Menurut dari pelaku tindak pidana perjudian togel online (wawancara 13 februari 2020) mengatakan bahwa $:^{18}$

"Modusnya yaitu para pemasang mulanya mengirimkan SMS kepada kami sebagai bandar kecil dan cara pembayarannya mereka mentransfer uang ke rekening kami sesuai dengan jumlah nomor yang mereka pasang, kemudian kami bandar kecil yang akan melakukan pemasangan nomor melalui website ke bandar besar, dan cara pembayarannya berbeda dengan bandar kecil, untuk pembayaran ke bandar besar kami melakukan tanam modal terlebih dahulu. Jadi jika pada saat kami melakukan togel online kemudian kalah maka bandar besar akan mengambil langsung uang di rekening kami dan jika kami menang maka bandar besar akan mentransfer uang tersebut ke rekening kami, dan bandar besar sudah mengetahui nomor rekening kami karena kami melakukan kerja sama dengan mereka. Setiap bandar-bandar kecil yang melakukan togel online itu masing-masing sudah ada email dan password. Dan juga dalam permaian togel online ini untuk bandar-bandar kecil bisa langsung melakukan pemasangan ke bandar pusat, tidak lagi bertahap-tahap. Dalam perjudian togel online ini siapa saja bisa jadi bandar kecil, asalkan mempunyai modal besar. Untuk melihat putarannya atau melihat siapa yang menang, kami bisa lihat langsung dengan cara membuka lewat google/situs online. Pengumuman pemenangnya pun bermacam-macam, ada yang di umumkan setiap hari dan

18 Hasil wawancara bersama AT, Pelaku Tindak Pidana Perjudian di kota gorontalo, Kamis 13 Februari 2020 ada pula yang diumumkan pada hari tertentu saja. Dan dalam togel online ini jaringannya berbeda-beda."

Menurut masyarakat sendiri (wawancara 13 februari 2020) $:^{19}$

Kasus judi online ataupun perjudian dari hari ke hari semakin marak. Masalah judi online ataupun perjudian merupakan masalah klasik yang menjadi kebiasaan yang salah, bagi umat manusia. Sejalan dengan perkembangan kehidupan masyarakat, ilmu pengetahuan, teknologi dan globalisasi maka tingkat dan modus kriminalitas juga mengalami perubahan baik kualitas maupun kuantitasnya. Pada hakekatnya judi online maupun perjudian jelas-jelas bertentangan dengan agama, kesusilaan, dan moral Pancasila, serta membahayakan bagi penghidupan dan kehidupan masyarakat, bangsa dan negara.

Kemudahan masyarakat untuk memperoleh informasi dari dunia luar dengan memanfaatkan kemajuan fasilitas teknologi informasi dan sebagai dampak langsung globalisasi dalam era reformasi maka pengaruh buruk terhadap sesuatu hal secara langsung akan dirasakan oleh masyarakat, apalagi bagi masyarakat yang taraf pendidikan dan ekonominya menengah ke bawah. Sebagai

19 Hasil wawancara dengan RO, sebagai masyarakat setempat, Kamis 13 Februari 2020 
dampaknya jalan pintas untuk memperoleh sesuatu bukan hal yang diharapkan lagi, termasuk judi online dan perjudian.

Dari pendapat masyarakat yang di jelaskan di atas, maka jelaslah apa yang sebenarnya yang dimaksud pengertian judi oleh masyarakat, yaitu setiap permainan atau perbuatan yang sifatnya untung-untungan atau dengan mempergunakan uang atau barang sebagai taruhannya.

Permainan judi menurut masyarakat, mengandung unsur yang meliputi:

1) Ada permainan atau perbuatan manusia.

2) Bersifat untung-untungan atau tidak.

3) Dengan menggunakan uang atau barang sebagai taruhannya jadi yang dikatakan judi, harus memenuhi tiga unsur tersebut di atas.

Faktor dominan penyebab terjadinya kejahatan perjudian online yang dilakukan oleh masyarakat adalah faktor lingkungan yang sangat berpengaruh bagi perilaku dan karakter seseorang. Selain faktor lingkungan, faktor penyebab seseorang bermain judi online adalah faktor keluarga dan Internet (teknologi informasi). Keluarga yang seharusnya menjadi pelindung bagi anggota keluarganya yang lain malah memberikan ancaman yang sangat besar bagi sebagian anggota dalam keluarganya. Ini tentu saja sangat memprihatinkan. Perkembangan teknologi juga mengambil peranan penting dalam sebuah hubungan keluarga. Salah satunya dengan media sosialnya. Indonesia adalah pengguna Facebook terbanyak di dunia.

Kemudian modus operandi pelaku perjudian togel online adalah untuk mendapatkan keuntungan yang sebesarbesarnya tanpa harus berusaha. Pelaku pada umumnya hanya memikirkan aspek ekonomi yang dapat diperoleh dalam waktu yang relatif singkat tanpa memikirkan akibat yang timbul. Adapun masalah yang akan timbul akibat dari perjudian ini adalah orang akan menjadi ketagihan bermain judi, mereka tidak dapat berhenti berjudi dan akhirnya akan kehilangan uangnya. Jadi, judi akan merugikan diri sendiri, dan dapat merusak perekonomian masyarakat itu sendiri. Selain rugi uang, kesehatan dan mental, juga dapat membuat orang yang berjudi menjadi pemalas, dan pada akhirnya akan berbuat kriminal seperti mencuri, merampok, dan bahkan membunuh. Dengan demikian, perjudian bisa menjadi sebab seseorang melakukan kriminal, penyebab kemiskinan, membuat orang jadi malas bekerja, bahkan membuat penjudi jadi sakit jiwa, stress, dan gila disebabkan dengan 
akan mendapatkan uang banyak. Golongan yang berasumsi bahwa togel online merupakan alternatif perolehan penghasilan yang tinggi ini menganggap judi togel merupakan perbuatan yang biasa dengan berpedoman pada falsafah menghalalkan segala cara untuk mencapai tujuan meskipun perbuatan tersebut jelas bertentangan dengan falsafah Pancasila dan kebijakan peraturan perundang-undangan yang berlaku. Langkah utama yang dilakukan pelaku untuk melakukan perjudian togel berbasis online adalah mengetahui terlebih dahulu kualitas sebuah agen togel online.

Apabila agen tersebut dirasa memiliki kapasitas yang layak sebagai wadah perjudian, pelaku akan memasang angka dengan melakukan pembayaran melalui akun rekening yang disediakan oleh agen togel online. Agen togel online atau biasa yang dikenal sebagai bandar menyediakan website yang terverifikasi dan memiliki kepercayaan yang tinggi dari para pemain yang turut berpartisipasi dalam website tersebut. Dikarenakan sistem perjudian yang terintegrasi dengan ketersediaan aparat penegak hukum yang terbatas, menyebabkan perjudian togel jenis ini sulit untuk ditanggulangi. Apabila dikaitkan dengan upaya penal kebijakan hukum pidana, kejahatan tersebut sudah tidak lagi relevan dengan metode penal. Kemudian jika dikaitkan dengan upaya non - penal, pelaku togel online tidak akan menghiraukan metode tersebut dikarenakan pelaku kejahatan tersebut pada hakikatnya mengetahui bagaimana hukum mengaturnya, namun kesadaran yang tergolong rendah menyebabkan pelaku enggan untuk mematuhinya.

Secara ringkas, faktor-faktor yang mempengaruhi berkembangnya perjudian online di Indonesia yaitu, Pertama, Pemerintah yang dalam hal ini adalah kementerian terkait, sangat minim melakukan upaya preventif (misalnya melalui upaya pemblokiran sebagaimana yang dilakukan terhadap situs - situs pornografi). Kenyataan ini dapat dilihat dari banyaknya situs - situs judi online yang bebas beroperasi lengkap dengan situs - situs referal dan situs dari para agennya. Bahkan secara terang - terangan mempromosikan situsnya melalui fasilitas iklan berbayar yang disediakan oleh mesin pencari seperti Google. Kedua, penyalahgunaan fasilitas perbankan. Maraknya perjudian online tentunya tidak bisa dilepaskan dari adanya berbagai fasilitas perbankan yang ada pada saat ini seperti Auto Teller Machine (ATM), Internet Banking, Mobile Banking dan lain-lain. Dengan berbagai fasilitas perbankan tersebut, sangat 
mempermudah proses pembayaran dari pihak pemain kepada pihak pengelola dan sebaliknya.

Pihak Polres Gorontalo Kota menjelaskan bahwa dalam penanganan kasus judi online di Kota Gorontalo hanya ditemukan beberapa kasus namun tidak banyak. Dan dalam penanganan kasus judi online pun mengalami beragam hambatan yang ditemukan di lapangan baik dari segi waktu, biaya, dan proses yang tidak mudah dibayangkan. Hal ini jika menginginkan proses penegakan hukum yang maksimal dengan menerapkan UU ITE. Berdasarkan hasil wawancara, maka terkait kasus penanganan judi online dengan menerapkan sepenuhnya UU ITE yang berkaitan dengan itu, belum diterapkan di Polres Gorontalo Kota. Salah satunya adalah faktor biaya dalam mendatangkan saksi ahli yang membutuhkan biaya banyak dalam proses pemberkasan, selain itu juga dalam proses bedah forensik yang dilakukan terhadap barang bukti masih ditemukan banyak kendala

\section{PENUTUP}

\section{A. KESIMPULAN}

Berdasarkan pembahasan yang telah diuraikan diatas, akhirnya penulis menarik kesimpulan, yakni: Pertama, upaya yang dilakukan oleh kepolisian dalam penanganan tindak pidana perjudian togel online yaitu:
Preventif dan Represif. Pertama, Faktor penghambat dalam penanggulangan tindak pidana perjudian togel online di kota gorontalo Peran kepolisian dalam menangani kasus perjudian online belum begitu efektif dikarenakan masih adanya hambatanhambatan yang ditemukan dalam proses penanggulangan tindak pidana tersebut, diantaranya adalah kendala IT yang masih terbatas, sehingga terhadap pelaku judi tersebut hanya dikenakan Pasal 303 KUHP tentang perjudian. Dan dalam penanganan kasus judi online pun mengalami beragam hambatan yang ditemukan dilapangan baik dari segi waktu, biaya dan proses yang tidak mudah dibayangkan.

\section{B. REKOMENDASI}

Pertama, Kepada pihak kepolisian agar lebih serius lagi dalam menangani dan mengungkap kasus perjudian yang semakin marak terjadi dalam berbagai bentuk atau jenis yang telah maupun yang akan terjadi di kota Gorontalo. Kedua, Pihak kepolisian harus lebih mendekatkan diri lagi kepada masyarakat agar dapat menjalin kerja sama yang baik. Sehingganya dapat membangun suatu pola transparansi dari masyarakat mengenai informasi-informasi yang dibutuhkan oleh pihak kepolisian guna mencegah terjadinya atau makin meluasnya tindak pidana judi togel ini. Ketiga, Penulis 
berharap kepada oknum yang berwenang dalam pembuatan aturan, agar kiranya membuat aturan secara khusus mengenai perjudian online, karena dengan berkembangnya teknologi semakin cepat maka modus dan bentuk perjudian melalui media online tidak akan lagi sesuai dengan aturan yang ada. Keempat, Diharapkan masyarakat ikut berpartisipasi melaporkan kepada pihak kepolisian bila melihat, menemukan dan menyaksikan adanya tindakan perjudian.

\section{REFERENSI}

\section{Buku:}

Kartono, Kartini, Patologi Sosial Jilid 1. (Jakarta: Rajagrafindo Persada, 2011).

Mulyana W Kusuma, Kejahatan Dan Penyimpangan, (Jakarta : YLBHI, 1988),

Sadijono, Hukum Kepolisian, (Yogyakarta: Laksbang Pressindo, 2006).

\section{Jurnal:}

Asrul Azis. 2012. "Perkembangan Hukum Mengenai Pemberantasan Judi Toto Gelap (Togel) dalam Perspektif Kriminologi," Jurnal Ilmiah, Medan: Fakultas Hukum Universitas Sumatra Utara.

Duwi Handoko. 2018. Tindak Pidana Tanpa Korban Di Indonesia Pengaturan dan Problematikanya, Jurnal Menara Ilmu, 3 (3).

Karolina Sitepu. 2015. Pemberantasan dan Penanggulangan Tindak Pidana Perjudian Togel di Wilayah Hukum
Polresta Medan, Jurnal Ilmiah, Medan: "RESEARCH SAINS" 1 (1).

Yuda Pramudia Zen, Skripsi: "Upaya kepolisian dalam menanggulangi tindak pidana perjudian yang dilakukan oleh remaja di wilayah hukum kepolisian resor kota padang", (Padang: Universitas Andalas, 2017).

Muh Nur Fadlan, Skripsi: "Tinjauan Yuridis Terhadap Tindak Pidana Perjudian Di Kabupaten Gowa Tahun 2006-2011", (Makassar: UIN Alauddin, 2012), https://docplayer.info/37550461-Perankepolisian-dalam-memberantastindak-pidana-judi-sabung-ayam-dikota-gorontalo-studi-kasus-dipolres-gorontalo-kota.html. Diakses pada 24 Oktober pukul 12.12.

\section{Peraturan Perundang Undangan:}

Undang-Undang Nomor 7 Tahun 1947 Tentang Penertiban Perjudian Kitab Undang-Undang Hukum Pidana 